\title{
TDZD-8 Suppresses Rheumatoid Arthritis Induced by Collagen Type II in Rats: Potential Role of Apoptosis and Inflammation
}

\author{
TDZD-8 Suprime la Artritis Reumatoide Inducida por Colágeno Tipo \\ II en Ratas: Papel Potencial de la Apoptosis y la Inflamación
}

Amal F. Dawood

DAWOOD, A. F. TDZD-8 suppresses rheumatoid arthritis induced by collagen type ii in rats: Potential role of apoptosis and inflammation. Int. J. Morphol., 39(1):311-317, 2021.

SUMMARY: Rheumatoid arthritis (RA) is considered an autoimmune disease distinguished by chronic synovial membrane inflammation, degraded cartilage, as well as bone destruction, which lead to joints pain and stiffness. The pathogenesis of RA involved at least two mechanisms: Cellular proliferation and activation of glycogen synthase kinase- $3 \beta$ (GSK3 $\beta$ ) enzyme. Thus, we tested the hypothesis that the GSK3binhibitor, TDZD-8, can treat the synovial tissue toward collagen type II (COII)-mediated RA linked to apoptosis induction and biomarker suppression of inflammation. Wistar rats were immunized with COII (the model group) for 21 days. Matched immunized rats were daily injected with TDZD-8 $(1 \mathrm{mg} / \mathrm{kg}$; i.p) for three additional weeks (COII+TDZD8).After 42 days of post-immunization, blood and tissues were collected. Histology (H\&E) and immunohistochemistry (CD45; leukocyte common antigen) images showed that COII induced RA was demonstrated by profound damage to the synovial tissue and infiltration of the inflammatory cells, which were substantially ameliorated with TDZD-8. In addition, COII immunization caused the induction of rheumatoid factor (RF), tumor necrosis factor-alpha (TNF- $\alpha$ ), interleukin-6 (IL-6), and interleukin 1 beta (IL-1 $\beta$ ) that were substantially $(\mathrm{p}<0.05)$ suppressed by TDZD-8. Whereas, TDZD-8 augmented the apoptotic biomarker, Bcl-2-associated X protein (Bax), which was significantly $(\mathrm{p}<0.05)$ ameliorated by RA. We also showed a substantial relationship $(\mathrm{p}<0.001)$ between the blood levels of RF and the synovial tissue levels of TNF- $\alpha(r=0.759)$, IL-1b $(r=0.969)$, IL-6 $(r=0.749)$, and $B a x(r=-0.914)$. These results indicate effective treatment of the injured synovial tissue by TDZD-8 against COII-induced RA in rats, which also decreases inflammatory biomarkers and augmentation of apoptosis.

KEY WORDS: Rheumatoid arthritis; TDZD-8; Bax; Inflammation; Rat model.

\section{INTRODUCTION}

RA, as chronic autoimmune joint disease, is most commonly found in hands, wrists, and knees, which can lead to the destruction of joints and eventually causes limited movements of joints (Smolen et al., 2018). It is more frequent and more severe in women than men by about two to three times (Ahlmén et al., 2009). Many cell types such as immune cells, synovial cells, and fibroblast-like synoviocytes are involved in RA (Guo et al., 2018), causing synovial tissue inflammation, synovial cell hyperplasia in addition to cartilage as well as joint destruction, leading to joint swelling and pain, localized degenerative discrepancies, deformation and ultimately disability (Scott et al., 2010; Shi et al., 2011).
GSK-3 $\beta$ is a serine/threonine kinase that is implicated in RA pathophysiology (Miao et al., 2013), and its inhibition significantly improved the clinical outcome (Hu et al., 2006; Beurel et al., 2010). GSK-3 $\beta$ activation caused the upregulation and down regulation of proinflammatory cytokines and anti-inflammatory cytokines production, respectively (Steinbrecher et al., 2005; Chan et al., 2009). Strikingly, many cells, such as natural killer (NK) cells, dendritic cells (DC), monocytes, macroph gederived cells, and T cells, showed the GSK-3 $\beta$ influences on these inflammatory modulators and cytokines (Beurel et al.). 
The two significant pathways leading to RA in humans, as well as animal models, are inflammation and proliferation that are found in synovial fibroblasts, macrophages, and lymphocytes (Pope 2002; Dhaouadi et al., 2007). The link between GSK-3 $\beta$, inflammation, and proliferation in the progressive destruction of joints due to RA(Yoshino \& Ishioka, 2015; Zhou et al., 2016) had prompted us to examine the potential therapeutic effects of the GSK-3 $\beta$ inhibitor TDZD8 against COII-induced RA in rats correlated with inflammation inhibition and anti-apoptosis.

\section{MATERIAL AND METHOD}

Animals. Wistar male rats $(160 \pm 10 \mathrm{~g}, 8$ weeks of age $)$ were obtained from the animal house at King Saud University (Riyadh, Saudi Arabia) and were used for all histology, immunohistochemistry, western blot analysis, and blood chemistry experiments. The rats obtained accessible food as well as water and were accommodated at a fixed temperature of $22{ }^{\circ} \mathrm{C}$ for $12 \mathrm{~h} \mathrm{light/dark} \mathrm{cycle.} \mathrm{The} \mathrm{utilized} \mathrm{experimental}$ methods within the study were consistent with laboratory animal care and use instructions, released by the US National Institutes of Health (NIH publication No. 85-23, revised 1996). Besides, it received authorization from the College of Medicine Ethical Committee at Princess Nourah University, Riyadh, Saudi Arabia.

Induction of rheumatoid arthritis (RA) by collagen type II (COII). RA was induced in rats by active immunization, as previously reported (Brand et al., 2007). Briefly, lyophilized bovine collagen type II (Sigma-Aldrich, MO, USA) emulsified in an equivalent volume of complete Freund's adjuvant (Sigma-Aldrich, MO, USA) were injected intra-dermally (i.d) at day 0 in $100 \mu \mathrm{L}$ volume at $200 \mu \mathrm{g}$ COII final concentration. A booster dose $(200 \mu \mathrm{g}$ in $100 \mu \mathrm{L})$ prepared in incomplete Freund's adjuvant (Sigma-Aldrich, MO, USA) was administered, i.d.on day 14. RA was confirmed on day 21 .

Experimental design. Within four groups, ( $\mathrm{n}=6$; each), 24 rats were assigned as follows: (1) Control group: from day 0 to day 14 , the rats received normal saline $(100 \mu \mathrm{l})$ via i.d. routeand between day 21 and day 42, they were exposed to a $100 \mu \mathrm{l}$ daily dose of $0.1 \%$ DMSO (i.p) ; (2) TDZD-8 control group: the rats were subjected to the above procedure and between day 21 and day 42, they were provided witha100 $\mu 1$ daily TDZD-8i.pdose $(1 \mathrm{mg} / \mathrm{kg}$ ) (Abcam, Cambridge, UK); (3) the model group (RA): actively immunized rats with COII (as mentioned above) had received, between day 21 and day 42, a $100 \mu \mathrm{l}$ volume of DMSO $(0.1 \%)$ to be used as a vehicle; and (4) the treated group (COII+TDZD8): the rats with RA had received a $100 \mu$ l daily TDZD-8 i.p dose $(1 \mathrm{mg} / \mathrm{kg})$ (Zhou et al.) between day 21 and day $42.1 \%$ diluted DMSO was used to dissolve TDZD-8.

Blood collection and isolation of the synovium. Rats were culled by cervical dislocation after being anesthetised with 50 $\mathrm{mg} / \mathrm{kg}$ sodium pentobarbital. Blood was collected, and sera were isolated and kept at $-20^{\circ} \mathrm{C}$ for biochemical investigation. Using a dissecting microscope, the removal of boths of tissue and ligaments on the patella of the exposed knee joints was realized, whereas the synovium was eliminated, snap-frozen (liquid nitrogen), and kept at $-80^{\circ} \mathrm{C}$ until being utilized.

Histological analysis. Harvested specimens obtained from synovium tissues were fixed for $24 \mathrm{~h}$ in formal saline (10\%), and paraffin blocks were prepared after dehydration of tissues in ascending alcohol grade. In order to analyze tissue histology, tissue sections ( $5 \mu \mathrm{m}$ thick) were stained with hematoxylin as well as eosin (H\&E).

CD45Immunohistochemistry. Deparaffinized synovium tissue sections ( $5 \mu \mathrm{m}$ thick) were dehydrated, and antigen retrieval was conducted in citrate buffer $(10 \mathrm{Mm}, \mathrm{pH} 6)$. To assess infiltrated leukocytes, sections were incubated with CD45 antibody (Abcam, cat \# ab10558) at room temperature (RT) for $1 \mathrm{~h}$, washed and incubated with the secondary antibody for $1 / 2 \mathrm{~h}$ at RT. Having counterstained the sections with the assistance of Meyer hematoxylin, the nucleus can be visualized.

Determination of blood levels of rheumatoid factor (RF). RF was assessed using ELISA kit provided by CUSABIO Technology LLC, TX, USA, and was utilized based on the recommendations of the manufacturer.

Western Blotting Analysis of Bax, TNF-alpha $\alpha$, IL-1 $\beta$, and IL-6. As previously reported (Al-Ani et al., 2010), extracted protein $(40 \mu \mathrm{g}$ per sample) from synovial tissues were western blotted using anti-Bax (Cell Signalling Technology, USA), anti-TNF- $\alpha$ (Santa Cruz Biotechnology), anti-IL-1 $\beta$ (Santa Cruz Biotechnology), and anti-IL-6 (Santa Cruz Biotechnology). ECL detection kit (Thermo Fisher Scientific Inc, Rockford, IL, USA) was employed for visualizing the protein bands. To measure band intensities, image analysis software (C-Di Git blot scanner; LI-COR, NE, USA) was used.

Statistical analysis. The statistical software package of GraphPad Prism (version 6) was used to perform the statistical analysis. The assessment of the discrepancies among the studied four groups was realized when one-way ANOVA was performed, accompanied by Tukey's test. In addition, data were described as mean $\pm \mathrm{SD}$, and the findings were found to be substantial when $\mathrm{P} \leq 0.05$. 


\section{RESULTS}

TDZD-8 partially inhibits COII-induced synovium proliferation and tissue infiltration of inflammatory cells. After 21 days on TDZD-8 following the completion of the immunization regimen, harvested synovial tissues were stained with $\mathrm{H} \& \mathrm{E}$ and CD45 immunostaining and analysed by light microscopy. In comparison to unchanged tissue architecture in the control groups (Fig. 1A), COII substantially damaged the synovial membrane, as demonstrated by severing synoviocyte hyperplasia and infiltration of the inflammatory cells into the subsynovium (Fig. 1B). TDZD-8 treatment (Fig. 1C) substantially preserved synovial tissue architecture. However, infiltrations of a few inflammatory cells were still be seen. Furthermore, immunohistochemical staining for CD45 in synovial tissue sections of the model group (COII) showed strong positive CD45 stained cells (Fig. 1E) compared to negative to weakCD45 stained cells in the control group (Fig. 1D) that were considerably $(p<0.05)$ but not entirely suppressed by means ofTDZD-8 in the COII+TDZD-8 group (Fig. 1F).
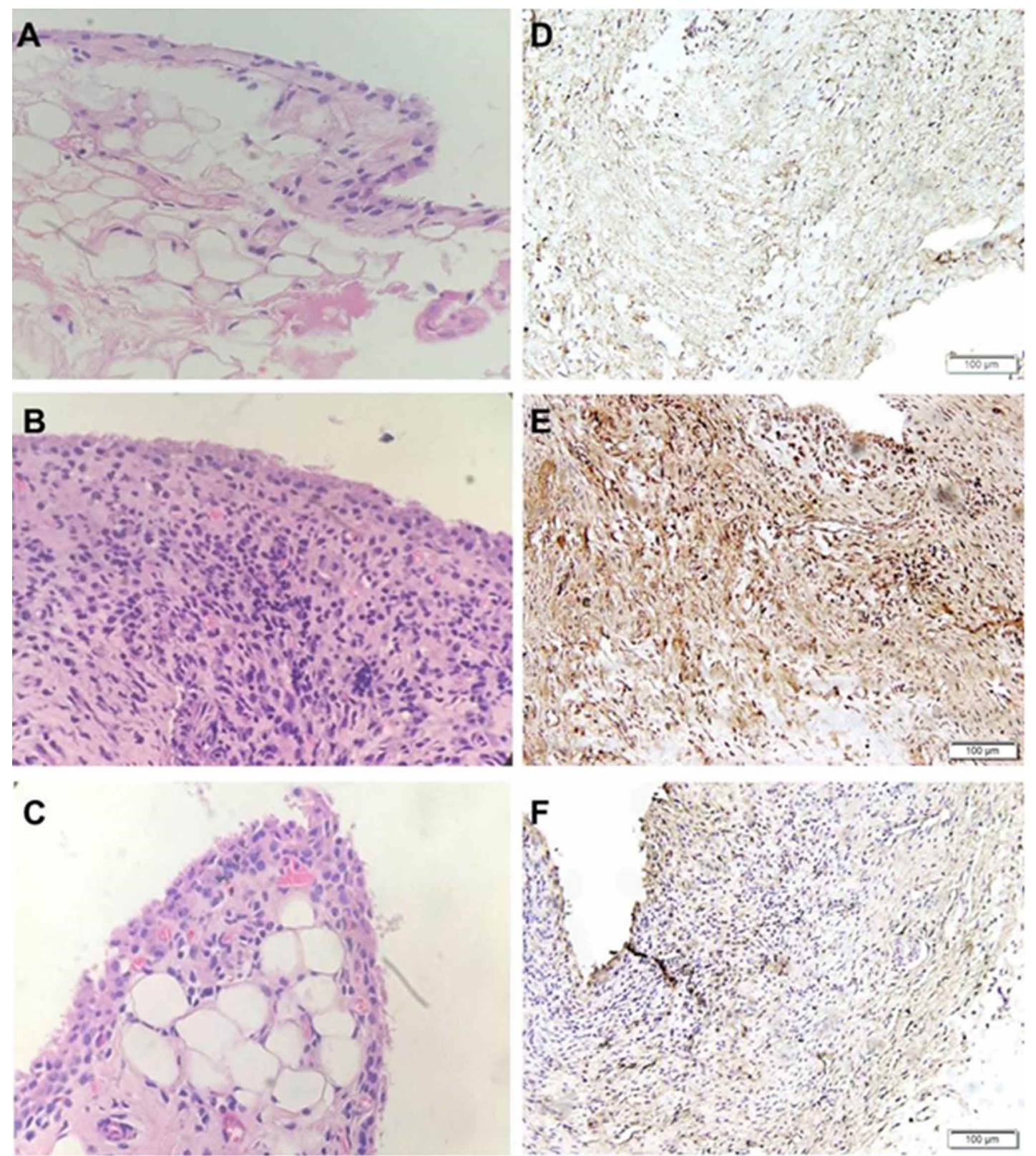

Fig. 1. Inhibition of COII-induced synovial tissue injury and CD45 expression by TDZD-8. H\&E stained (A,B,C, x200) and CD45 immunostained (D, E, F x100) images from the knee joint synovial membrane of the control group (A and D),COII group (B and E), and the treated group, COII+TDZD-8 (D and F) of rats are depicted. 
TDZD-8 inhibits inflammation induced by COII immunization. To investigate if the detected synovial tissue damage caused by COII in our animal model of the disease was also linked with the induction of inflammatory biomarkers that are included in the RA pathogenesis (Myouzen et al., 2012), we assessed the protein expression of TNF- $\alpha$ and IL- 6 in the synovium of all animal groups. Active immunization of rats with COII caused a sharp

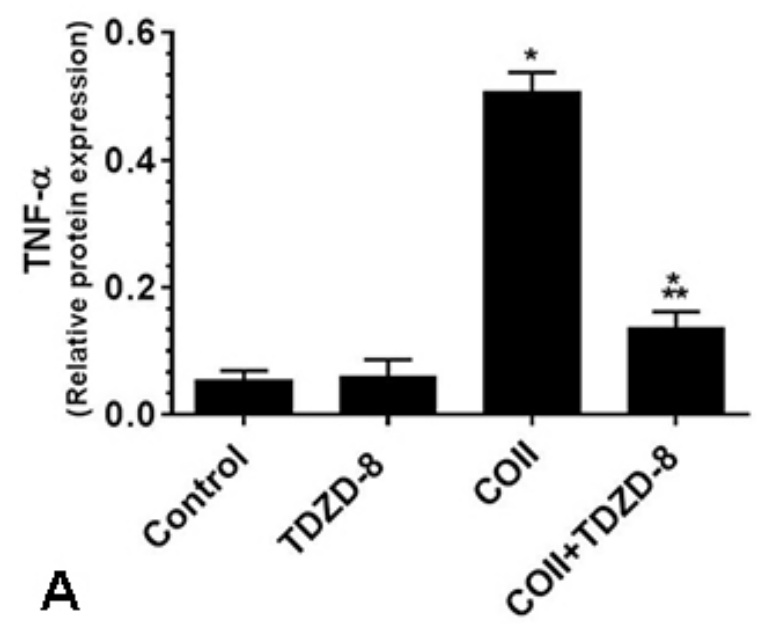

increase in synovial TNF- $\alpha$ (Fig. 2A) and IL-6 (Fig. 2B) in the model group (COII) compared with the control groups (Control and TDZD-8) of rats. Treatment of COII rats with TDZD-8 (COII+TDZD-8) for 21 days post-RA induction significantly $(\mathrm{p}<0.05)$ inhibited TNF- $\alpha$ and IL- 6 . However, the levels of such parameters in the COII+TDZD- 8 group were still important $(\mathrm{p}<0.05)$ in comparison with the control group (Fig. 2).

Fig. 2. Inhibition of COII-induced synovial tissue inflammatory biomarkers TNF-alpha? and IL-6 by TDZD-8. Synovial tissue homogenates levels of TNF- $\alpha$ (A) and IL-6 (B) were measured in all rats' groups; Control groups (Control, TDZD-8), model group (COII), and treated group (COII+TDZD-8). Findings exemplify the mean $( \pm \mathrm{SD}) ; \mathrm{n}=6$ for each group. The experiments were conducted in triplicate. ${ }^{*} \mathrm{p}<0.05$ versus control, $* * \mathrm{p}<0.05$ versus COII.

TDZD-8 inhibits COII-modulated apoptosis and rheumatoid factor (RF). To determine whether TDZD-8 can activate the apoptotic biomarker Bax that is located downstream of biomarkers of inflammation (Malemud,

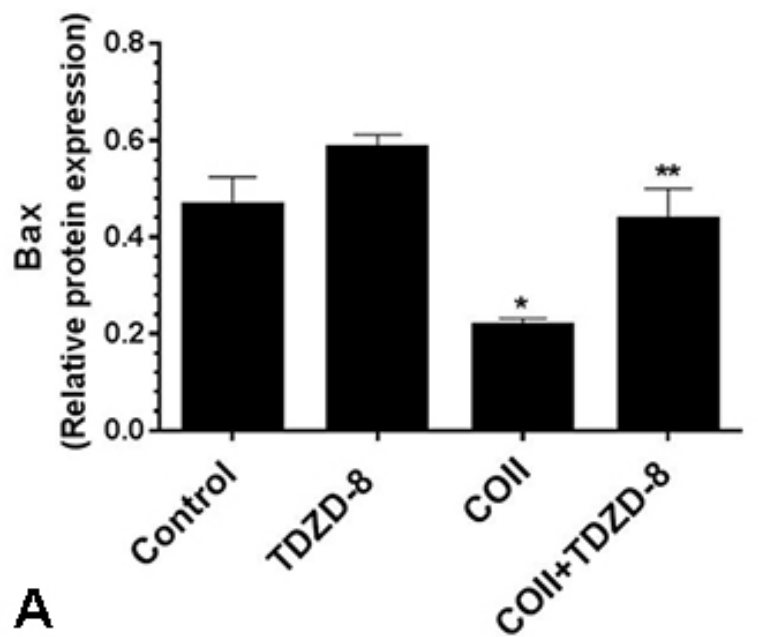

2013), we assessed Bax protein expression in the synovial membrane using western blotting approach (Fig. 3A). RA significantly $(\mathrm{p}<0.05)$ inhibited Bax, and TDZD-8 was able to restore Bax to levels similar to the control group.

Fig. 3. Inhibition of COII-induced synovial tissue apoptotic biomarker Bax and blood levels of RAbiomarker RF by TDZD-8. Synovial tissue homogenates levels of Bax (A) and blood levels of RF auto antibody (B) were measured in rats' groups,control groups (Control, TDZD-8), model group (COII), and treated group (COII+TDZD-8). Findings signify the mean $( \pm S D) ; n=6$ for each group. The experiments were performedin triplicate. ${ }^{*} \mathrm{p}<0.05$ versus control, $* * \mathrm{p}<0.05$ versus COII. 
To determine whether the treatment protocol by TDZD-8 used here can inhibit RF, which is a well-known RA marker (Gavrila et al., 2016; Lu et al., 2018), we assessed, in the four groups of rats, the RF blood levels. As shown in Figure 3B, immunization of rats with COII substantially $(\mathrm{p}<0.05)$ augmented RF levels in the model group (COII) that were substantially $(\mathrm{p}<0.05)$ but incompletely suppressed by COII+TDZD-8since the levels of RF in the treated group (COII+TDZD-8) were higher compared with control rats.
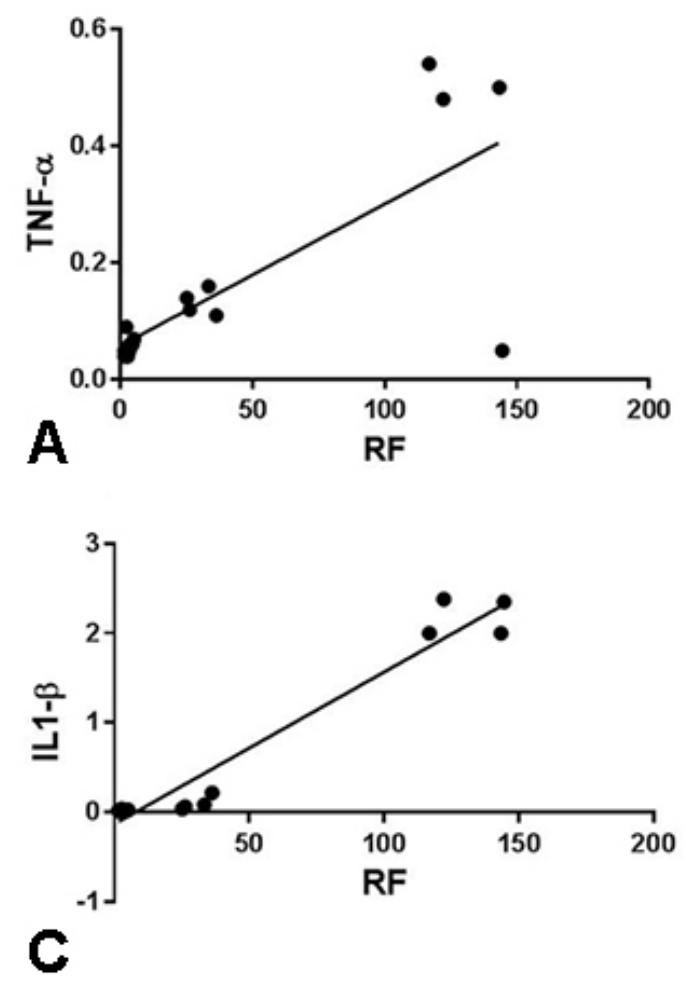

Correlation between rheumatoid factor and biomarkers of inflammation and apoptosis. The correlation between the scoring of RF and biomarkers of inflammation and apoptosis were evaluated to further promote TDZD- 8 as a suitablec ompound in RA, and also to endorse the link between RF and synovial injury. Figures $4 \mathrm{~A}, 4 \mathrm{~B}$, and $4 \mathrm{C}$ display a positive relationship between $\mathrm{RF}$ and the following parameters; $\mathrm{RF}$ versus TNF- $\alpha(\mathrm{r}=0.759)(\mathrm{p}=0.0007)$, RF versus $\mathrm{IL}-1 \beta$ $(r=0.969)(p<0.0001)$, and RF versus IL-6 $(r=0.749)(p=$ $0.0008)$. Whereas, a negative correlation was shown between RF and Bax $(r=-0.914)(p<0.0001)($ Fig.4D).
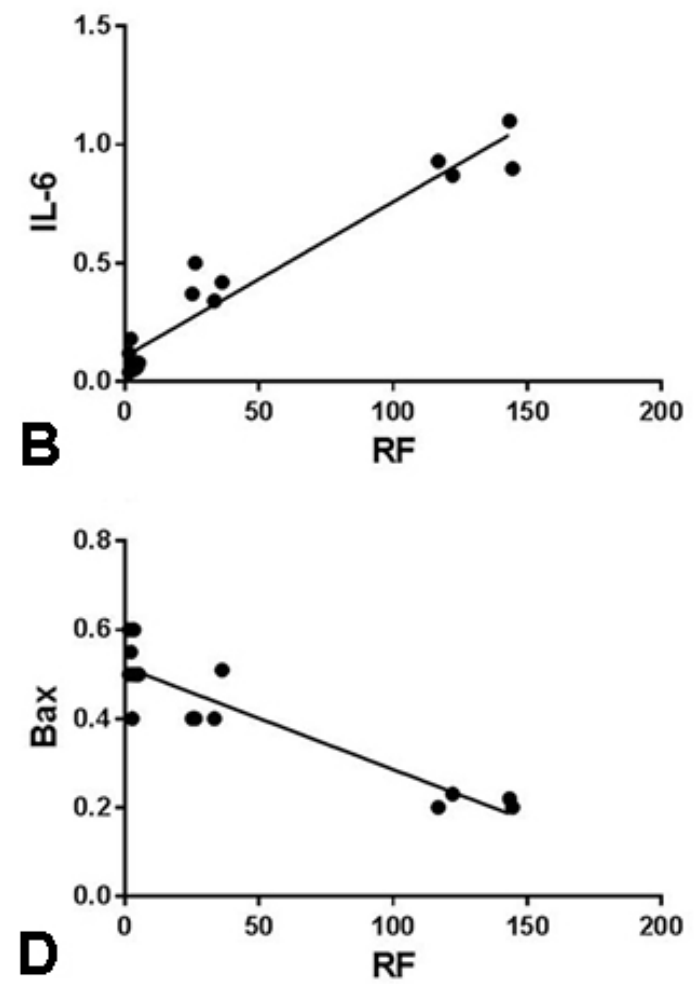

Fig. 4. Correlation between RF scoring and inflammatory biomarkers and apoptosis. Blood RF levels were measured in all used rats, and the correlation between RF and TNF- $\alpha$, RF and IL-6, RF and IL-1 $\beta$, and RF and Baxis shown in (A-D), respectively. RF: rheumatoid factor; TNF- $\alpha$ : tumor necrosis factor alpha; IL-6: interleukin 6; Bax: BCL2 associated X.

\section{DISCUSSION}

In this report, we examined the architecture of the synovial membrane in COII-induced RA in rats with and without the GSK3 $\beta$ inhibitor, TDZD-8. Also, TDZD-8 treatment protocol was used to evaluate the blood and tissue levels of rheumatoid factor, apoptosis, and inflammatory biomarkers. Therefore, rats were treated for three weeks with TDZD-8 post the induction of RA via active immunization with COII. Here, we demonstrated thatTDZD-8 markedly inhibits synovial tissue damage and infiltrations of inflammatory cells, and significantly but not completely inhibits the modulation of inflammatory biomarkers, RA, and apoptosis in COII-induced RA in rats.

The above conclusions are reinforced by our data that show COII caused a substantial injury to the synovial tissue structure (Fig. 1B) and induced biomarkers of (i) leukocyte 
infiltration (CD45, Fig. 1E); (ii) inflammation, TNF- $\alpha$ (Fig. 2A) and IL-6 (Fig. 2B); and (iii) RF (Fig. 3B), which were substantially treated by TDZD-8 (Figs. 1-4). Also, we demonstrate that COII inhibited the synovial protein expression of the apoptotic biomarker, Bax, which was significantly augmented by TDZD-8 to control levels (Fig. $3 \mathrm{~A})$. Therefore, ourdata are in agreement with our employed hypothesis, in which TDZD-8 can substantially treat RA induced by COII in rats.

The findings of this study confirm those previously published in literature and show that GSK3 $\beta$ inhibition ameliorates several pathological manifestations connected with COII-induced RA in human-derived cells and animal models (Pope; Cuzzocrea et al., 2006; Bao et al., 2007; Kwon et al., 2014). For example, (i) levels of pro-inflammatory mediators were reduced in fibroblast-like synoviocytes in the case of RA patients when they were treated with the GSK3 $\beta$ inhibitors (Kwon et al.); (ii) TDZD-8 reduces COIIinduced RA in mice since it improved joint and paw histology, reduced tissue levels of inducible nitric oxide synthase (iNOS) and blood TNF- $\alpha$ (Cuzzocrea et al.); (iii) apoptosis is proposed as a therapeutic tool in RA (Pope); and (iv) TDZD-8 weakens asthma in mice (Bao et al.). We conclude that TDZD-8 augments the apoptotic biomarker Bax and inhibits inflammation and inflammatory cells infiltration in the synovial membrane in a rat model of RA mediated by COII.

\section{ACKNOWLEDGMENTS}

The author would like to thank Professors Bahjat AlAni and Mohamed A. Haidara from the Department of Physiology, College of Medicine, King Khalid University, Abha, Saudi Arabia, and Dr. Samaa S Kamar from the Department of Medical Histology, Kasr Al-Aini Faculty of Medicine, Cairo University, Cairo, Egypt, for their input and help during the preparation of this manuscript. Besides, the author extends his appreciation to Dr. Mariam Al-Ani from Dental Care Partnership, Sutton Coldfield, Birmingham, UK, for her role in proof reading the manuscript.

DAWOOD, A. F. TDZD-8 suprime la artritis reumatoide inducida por colágeno tipo II en ratas: papel potencial de la apoptosis y la inflamación. Int. J. Morphol., 39(1):311-317, 2021.

RESUMEN: La artritis reumatoide (AR) es una enfermedad autoinmune que se distingue por la inflamación crónica de la membrana sinovial, el cartílago degradado y la destrucción de los huesos, lo que provoca dolor y rigidez en las articulaciones. La patogenia de la AR involucra al menos dos mecanismos: la proli- feración celular y la activación de la enzima glucógeno sintasa quinasa-3b (GSK3 $\beta$ ) Por lo tanto, probamos la hipótesis de que el inhibidor de GSK3 $\beta$, TDZD-8, puede tratar el tejido sinovial hacia el colágeno tipo II (COII) - AR mediada por inducción de apoptosis y supresión de biomarcadores de inflamación. Se inmunizaron ratas Wistar con COII (el grupo modelo) durante 21 días. Se inyectaron diariamente ratas emparejadas inmunizadas con TDZD-8 (1 $\mathrm{mg} / \mathrm{kg}$; i.p) durante tres semanas adicionales (COII + TDZD-8). Después de 42 días de post-inmunización, se recolectó sangre y tejidos. Las imágenes de histología (H\&E) e inmunohistoquímica (CD45; antígeno común de leucocitos) mostraron que la AR inducida por COII presentaba un daño profundo en el tejido sinovial e infiltración de las células inflamatorias, las que mejoraron con TDZD-8. Además, la inmunización con COII provocó la inducción de factor reumatoide (FR), factor de necrosis tumoral alfa (TNF- $\alpha$ ), interleucina-6 (IL-6) e interleucina 1 beta (IL-1 $\beta$ ) que fueron suprimidos por TDZD-8 de manera significativa $(\mathrm{p}<0.05)$. Considerando que TDZD-8 aumentó el biomarcador apoptótico, la proteína $\mathrm{X}$ asociada a Bcl-2 (Bax), que fue mejorado $(\mathrm{p}<0,05)$ por RA. También se observó una relación sustancial $(\mathrm{p}<0,001)$ entre los niveles sanguíneos de RF y los niveles de tejido sinovial de TNF- $\alpha(r=0,759)$, IL-1 $\beta(r=0,969)$, IL-6 $(r=0,749)$, y Bax $(r$ $=-0,914)$. Estos resultados indicaron un tratamiento eficaz del tejido sinovial lesionado por TDZD-8 contra la AR inducida por COII en ratas, que también disminuye los biomarcadores inflamatorios y el aumento de la apoptosis.

PALABRAS CLAVE: Artritis reumatoide; TDZD-8; Bax; Inflamación; Modelo de rata.

\section{REFERENCES}

Ahlmén, M.; Svensson, B.; Albertsson, K.; Forslind, K.; Hafström, I. \& BARFOT Study Group. Influence of gender on assessments of disease activity and function in early rheumatoid arthritis in relation to radiographic joint damage. Ann. Rheum. Dis., 69(1):230-3, 2009.

Al-Ani, B.; Hewett, P. W.; Cudmore, M. J.; Fujisawa, T.; Saifeddine, M.; Williams, H.; Ramma, W.; Sissaoui, S.; Jayaraman, P. S.; Ohba, M.; et al. Activation of proteinase-activated receptor 2 stimulates soluble vascular endothelial growth factor receptor 1 release via epidermal growth factor receptor transactivation in endothelial cells. Hypertension, 55(3):689-97, 2010

Bao, Z.; Lim, S.; Liao, W.; Lin, Y.; Thiemermann, C.; Leung, B. P. \& Wong, W. S. Glycogen synthase kinase-3beta inhibition attenuates asthma in mice. Am. J. Respir. Crit. Care Med., 176(5):431-8, 2007.

Beurel, E.; Michalek, S. M. \& Jope, R. S. Innate and adaptive immune responses regulated by glycogen synthase kinase-3 (GSK3). Trends Immunol., 31(1):24, 2010.

Brand, D. D.; Latham, K. A. \& Rosloniec, E. F. Collagen-induced arthritis. Nat. Protoc., 2(5):1269-75, 2007

Chan, M. M. P.; Cheung, B. K. W.; Li, J. C. B.; Chan, L. L. Y. \& Lau, A. S. Y. A role for glycogen synthase kinase-3 in antagonizing mycobacterial immune evasion by negatively regulating IL-10 induction. J. Leukoc. Biol., 86(2):283-91, 2009.

Cuzzocrea, S.; Mazzon, E.; Di Paola, R.; Muia, C.; Crisafulli, C.; Dugo, L.; Collin, M.; Britti, D.; Caputi, A. P. \& Thiemermann, C. Glycogen synthase kinase-3beta inhibition attenuates the degree of arthritis caused by type II collagen in the mouse. Clin. Immunol., 120(1):57$67,2006$. 
Gavrila , B. I.; Ciofu, C. \& Stoica, V. Biomarkers in rheumatoid arthritis, what is new? J. Med. Life, 9(2):144-8, 2016.

Guo, Q.; Wang, Y.; Xu, D.; Nossent, J.; Pavlos, N. J. \& Xu, J. Rheumatoid arthritis: pathological mechanisms and modern pharmacologic therapies. Bone Res., 6:15, 2018.

Hu, X.; Paik, P. K.; Chen, J.; Yarilina, A.; Kockeritz, L.; Lu, T. T.; Woodgett, J. R. \& Ivashkiv, L. B. IFN-gamma suppresses IL-10 production and synergizes with TLR 2 by regulating GSK3 and CREB/AP-1 proteins. Immunity, 24(5):563-74, 2006.

Kwon, Y. J.; Yoon, C. H.; Lee, S. W.; Park, Y. B.; Lee, S. K. \& Park, M. C. Inhibition of glycogen synthase kinase-3b suppresses inflammatory responses in rheumatoid arthritis fibroblast-like synoviocytes and collagen-induced arthritis. Joint Bone Spine, 81(3):240-6, 2014.

Lu, T.; Zong, M.; Fan, S.; Lu, Y.; Yu, S. \& Fan, L. Thioredoxin 1 is associated with the proliferation and apoptosis of rheumatoid arthritis fibroblastlike synoviocytes. Clin. Rheumatol., 37(1):117-25, 2018.

Malemud, C. J. Intracellular signaling pathways in rheumatoid arthritis. $J$. Clin. Cell. Immunol., 4:160, 2013.

Miao, C. G.; Yang, Y. Y.; He, X.; Li, X. F.; Huang, C.; Huang, Y.; Zhang, L.; Lv, X. W.; Jin, Y. \& Li, J. Wnt signaling pathway in rheumatoid arthritis, with special emphasis on the different roles in synovial inflammation and bone remodeling. Cell. Signal., 25(10):2069-78, 2013.

Myouzen, K.; Kochi, Y.; Okada, Y.; Terao, C.; Suzuki, A.; Ikari, K.; Tsunoda, T.; Takahashi, A.; Kubo, M.; Taniguchi, A.; et al. Functional variants in NFKBIE and RTKN2 involved in activation of the NF-kB pathway are associated with rheumatoid arthritis in Japanese. PLoS Genet., 8(9):e1002949, 2012.

Pope, R. M. Apoptosis as a therapeutic tool in rheumatoid arthritis. Nat. Rev. Immunol., 2(7):527-35, 2002.

Scott, D. L.; Wolfe, F. \& Huizinga, T. W. J. Rheumatoid arthritis. Lancet, 376(9746):1094-108, 2010.

Shi, M.; Cui, F.; Liu, A. J.; Li, J.; Ma, H. J.; Cheng, M.; Yang, J. \& Zhang, Y. Protection of chronic intermittent hypobaric hypoxia against collagen-induced arthritis in rat through increasing apoptosis. Sheng Li Xиe Bao, 63(2):115-23, 2011.

Smolen, J. S.; Aletaha, D.; Barton, A.; Burmester, G. R.; Emery, P.; Firestein, G. S.; Kavanaugh, A.; McInnes, I. B.; Solomon, D. H.; Strand, V.; et al. Rheumatoid arthritis. Nat. Rev. Dis. Primers, 4:18001, 2018.

Steinbrecher, K. A.; Wilson 3rd, W.; Cogswell, P. C. \& Baldwin, A. S. Glycogen synthase kinase 3 beta functions to specify gene-specific, NFkappaB-dependent transcription. Mol. Cell. Biol., 25(19):8444-55, 2005.

Yoshino, Y. \& Ishioka, C. Inhibition of glycogen synthase kinase-3 beta induces apoptosis and mitotic catastrophe by disrupting centrosome regulation in cancer cells. Sci. Rep., 5:13249, 2015.

Zhou, H.; Liu, J.; Zeng, J.; Hu, B.; Fang, X. \& Li, L. Inhibition of GSK-3b alleviates collagen II-induced rheumatoid arthritis in rats. Med. Sci. Monit., 22:1047-52, 2016.

\author{
Corresponding author: \\ Amal F. Dawood \\ Department of Basic Medical Sciences \\ College of Medicine \\ Princess Nourah Bint AbdulrahmanUniversity \\ Riyadh \\ SAUDI ARABIA
}

Email: amal_tawadros@yahoo.com

Received: 17-08-2020

Accepted: 22-10-2020 